Akbar Sujiwa, Atmiasri dan Edi Purwanto: Sistem Kontrol Daya Otomatis Pada Perangkat Prototipe Desalinasi Dual Output Bertenaga Sel Surya

\title{
SISTEM KONTROL EFISIENSI DAYA OTOMATIS PADA PERANGKAT PROTOTIPE DESALINASI DUAL OUTPUT BERTENAGA SEL SURYA
}

\author{
Akbar Sujiwa ${ }^{1)}$, Atmiasri ${ }^{1)}$, dan Edi Purwanto ${ }^{1)}$ \\ 1) Program Studi Teknik Elektro, Fakultas Teknologi Industri, Universitas PGRI Adi Buana Surabaya \\ Email: akbarsujiwa@unipasby.ac.id
}

\begin{abstract}
Abstrak
Penggunaan energi terbarukan semakin banyak diterapkan dalam kehidupan sehari-hari, khususnya pada pemanfaatan energi dari matahari dengan bantuan perangkat sel surya. Energi dari sel surya secara luas dapat digunakan dalam memenuhi kebutuhan berbagai macam perangkat yang memerlukan energi listrik, salah satunya dapat digunakan sebagai sumber daya utama untuk pengoperasian perangkat prototipe desalinasi dual output. Perangkat ini memiliki fungsi dapat memproduksi air tawar dan kristal garam secara bersamaan melalui proses distilasi. Dengan menggunakan sel surya sebagai sumber daya utama, maka proses tersebut sangat ramah lingkungan dan murah dalam biaya operasionalnya, namun banyaknya energi listrik yang dibangkitkan oleh sel surya sangat tergantung dari cuaca di sekitarnya. Untuk mengefisienkan penggunaan energi sel surya maka peneliti memiliki solusi dengan menerapkan sensor suhu sebagai kontrol otomatis dalam menghidupkan dan mematikan elemen pemanas pada proses distilasi. Hasil yang didapat berupa sistem kontrol menggunakan perangkat mikrokontroler dan sensor suhu yang mampu secara akurat mengendalikan elemen pemanas dengan menyalakannya saat suhu di bawah $100^{\circ} \mathrm{C}$ dan mematikannya saat suhu di atas $100^{\circ} \mathrm{C}$ sehingga tidak terjadi pemborosan listrik saat proses distilasi pada suhu tinggi.
\end{abstract}

Kata Kunci : efisiensi, kontrol, sel surya, sensor suhu.

\begin{abstract}
The use of renewable energy is increasingly being applied in daily life, especially in the utilization of energy from the sun with the help of solar cell devices. Energy from solar cells can be widely used in variety of devices that require electrical energy, one of which can be used as the main resource for operational of dual output desalination prototype devices. This device has the function of being able to produce fresh water and salt crystals simultaneously through the distillation process. By using solar cells as the main resource, the process is very environmentally friendly and inexpensive in its operational costs, but the amount of electricity generated by solar cells depends on the weather around it. To increase efficiency energy of solar cells, the researchers have a solution by applying a temperature sensor as an automatic control to turning on and off the heating element in the distillation process. The results of this research are control system using microcontroller and temperature sensors that are able to accurately control heating elements by turning it on when the temperature is below $100^{\circ} \mathrm{C}$ and turning it off when the temperature is above $100^{\circ} \mathrm{C}$ so there is no waste of electrical source at high temperatures distillation process.
\end{abstract}

Keyword: efficiency, control, solar cell, temperature sensor.

26 Jurnal Teknik WAKTU Volume 17 Nomor 01 - Januari 2019 - ISSN: 1412:1867 


\section{PENDAhUluAN}

Air bersih merupakan kebutuhan pokok dari semua makhluk hidup tak terkecuali manusia. Konsumsi air tak sebatas sebagai air minum saja namun juga sangat diperlukan dalam kegiatan seharihari seperti mandi, mencuci, memasak, dan sebagainya. Oleh karena itu ketersediaan air bersih wajib dan sangat penting bagi seluruh masyarakat, namun ketersediaan air bersih masih menjadi kendala di beberapa wilayah Indonesia. Salah satu daerah yang mengalami kekurangan air bersih ada di daerah pesisir Jakarta Utara (R. F. Lubis, 2018).

Meski hidup di daerah tepi laut yang merupakan sumber air berlimpah, tapi sumber air tawar ternyata terkadang masih sulit ditemukan. Salah satu solusi khusus yang dapat diterapkan di wilayah pesisir yaitu dapat menggunakan sistem penyulingan air laut dengan destilasi. Penyuling dari sistem ini pada intinya menggunakan teknik penguapan/evaporasi air laut sehingga terpisah zat garam dengan air pelarutnya, sehingga diperoleh hasil berupa air yang dimurnikan (Zheng, 2017).

Selain air tawar ternyata keuntungan lain dari sistem ini dapat menghasilkan kristal garam sebagai bahan kebutuhan memasak yang diperoleh dari sisa proses distilasi (Sumada et al., 2018).

Dalam pemenuhan energi, manusia sangat bergantung pada alam khususnya penggunaan bahan bakar fosil. Ketergantungan energi fosil akan menimbulkan setidaknya tiga ancaman serius yaitu menipisnya cadangan minyak bumi, kenaikan/ketidakstabilan harga akibat permintaan yang lebih besar dari produksi minyak, dan polusi gas rumah kaca (terutama CO2) (A. Lubis, 2007). Kadar CO 2 saat ini disebut sebagai yang tertinggi selama 125.000 tahun belakangan. Hal ini menimbulkan ancaman serius bagi kehidupan makhluk hidup di muka bumi. Oleh karena itu, pengembangan dan implementasi bahan bakar terbarukan yang ramah lingkungan perlu mendapatkan perhatian serius (Service, 2005).

Transisi dari energi fosil ke sumber terbarukan mulai gencar dilakukan sejak abad ke-21. Sel surya merupakan salah satu energi terbarukan yang dapat mengubah energi matahari menjadi energi listrik (Sahoo and Kale, 2018). Sumber energi ini sangat ramah lingkungan dan murah dalam operasionalnya, namun juga memiliki kekurangan. Tegangan dan arus listrik yang dihasilkan oleh sel surya sangat tergantung dari cuaca lingkungan di sekitarnya. Karena arus listrik yang dihasilkan oleh sel surya sebanding dengan intensitas radiasi cahaya matahari yang diterima sel surya (Suryana and Ali, 2016).

Karena ketergantungan tersebut maka penggunaan daya dari perangkat prototipe desalinasi dual output bertenaga sel surya harus dapat digunakan seefisien mungkin. Oleh karena itu dalam penelitian ini akan diteliti bagaimana membuat suatu sistem untuk mengontrol efisiensi penggunaan daya selama penggunaan alat dan menentukan parameter suhu yang tetap dalam proses distilasi. Sistem kontrol yang dibangun berbasis sensor suhu yang menggunakan mikrokontroler sebagai pengolah dan pengendali otomatis dalam penggunaan sumber energi listrik yang dihasilkan oleh sel surya.

\section{METODE}

Pada penelitian ini diuji suatu perangkat sensor suhu dalam mengontrol proses otomatisasi distilasi air laut. Kontrol otomatis ini mengatur kerja elemen pemanas agar tidak melebihi suhu $100^{\circ} \mathrm{C}$ sehingga tidak terjadi pemborosan penggunaan tenaga listrik. Pelaksanaan penelitian dilakukan secara bertahap, dimulai dari tahap karakteristik sensor, penerapan sensor pada sistem yang dibuat, dan analisa hasil produk dari perangkat prototipe desalinasi dual output. Pada gambar 1 disajikan desain perangkat desalinasi yang digunakan dalam proses penelitian, secara umum perangkat ini dibangun dari komponen utama berupa panel surya dan baterai sebagai sumber tenaganya, serta dua buah tandon sebagai penampungan air laut dan hasil desalinasi. 


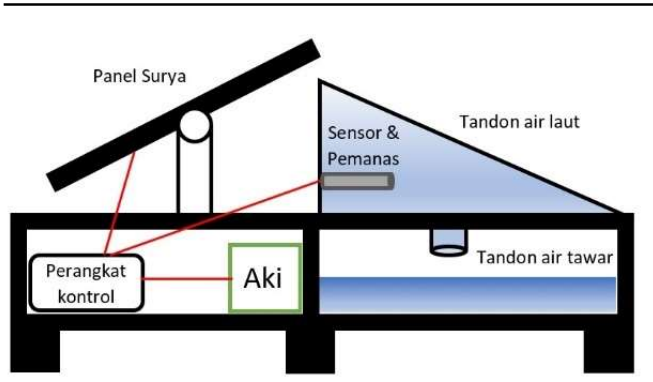

Gambar 1. Desain prototipe desalinasi dual output

Terdapat juga komponen tambahan berupa sensor LM35 yang merupakan sensor suhu, mikrokontroler Arduino Uno sebagai pengolah data dan LCD sebagai layar penunjuk suhu. Dalam perangkat ini juga ditambahkan elemen pemanas sebagai perangkat pemanas distilasi air laut. Secara garis besar perangkat ini ditenagai oleh sel surya, dan menerapkan distilasi dari proses pemanasan sehingga mampu memisahkan air laut menjadi air tawar dan kristal garam. Seluruh proses kerja dari perangkat ini di kontrol secara otomatis oleh perangkat mikrokontroler Arduino Uno.

Pada percobaan pertama dilakukan karakterisasi dari sensor LM35 untuk menentukan parameter sensor yang akan digunakan, rangkaian dari pengukuran karakterisasi sensor suhu ini ditunjukkan seperti gambar 2, di mana sensor suhu dihubungkan pada input ADC mikrokontroler yang kemudian mikrokontroler memberikan sinyal output pada LDC untuk menampilkan pembacaan suhu. Variabel bebas yang dipakai adalah perubahan suhu dari $30^{\circ} \mathrm{C}$ hingga suhu maksimal pengukuran $105^{\circ} \mathrm{C}$, dan variasi pengukuran dicatat tiap kenaikan $5^{\circ} \mathrm{C}$. Parameter yang didapat berupa nilai tegangan sensor yang sebanding dengan besar perubahan suhu yang terjadi. Dari parameter ini kemudian dijadikan suatu persamaan linier sebagai rumus dalam coding perangkat lunak yang dipakai. Kemudian dilakukan percobaan sekali lagi untuk memastikan suhu hasil konversi perangkat lunak telah sesuai dengan suhu sesungguhnya menggunakan variabel yang sama seperti sebelumnya.

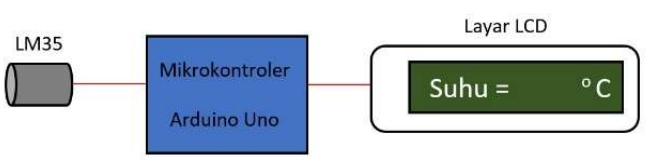

Gambar 2. Skematis rangkaian pengukur suhu LM35

Skematis dari rangkaian pengukur suhu dapat dilihat pada Gambar 2, sensor LM35 merupakan sensor yang hanya memerlukan sumber tegangan tanpa perlu tambahan rangkaian elektronik penunjang. Sehingga data berupa tegangan dari sensor dapat dibaca langsung oleh mikrokontroler kemudian diolah yang selanjutnya ditampilkan di layar LCD dalam bentuk satuan suhu Celsius.

Percobaan kedua di awali dengan menggabungkan sensor ke perangkat prototipe sebagai sensor pendeteksi suhu. Variabel bebas yang digunakan dalam percobaan ini berupa suhu operasional di dalam tandon penyimpanan air laut, sedangkan variabel terikat yang diperoleh berupa tegangan kerja dari elemen pemanas perangkat distilasi. Fungsi dari mikrokontroler di sini adalah memastikan bahwa ketika suhu pemanas berada pada di bawah $100^{\circ} \mathrm{C}$ tegangan sebesar $220 \mathrm{~V}$ mulai dialirkan ke elemen pemanas, sedangkan saat suhu mencapai lebih dari $100^{\circ} \mathrm{C}$ tegangan elemen pemanas diputus untuk menghemat energi.

\section{HASIL DAN PEMBAHASAN}

Dalam pelaksanaan penelitian ini digunakan perangkat desalinasi air laut yang dibangun secara mandiri oleh peneliti. Secara singkat fungsi utama dari perangkat yang dibangun, adalah digunakan untuk memisahkan air tawar dan kristal garam yang terkandung di dalam air laut. Kemampuan lain dari perangkat ini tidak memerlukan sumber energi yang mencemari lingkungan karena menggunakan sumber energi terbarukan berupa sel surya dan turbin angin.

Dalam penelitian ini telah dilaksanakan serangkaian uji coba guna karakterisasi sistem yang diinginkan, antara lain. 
Karakterisasi Sensor Suhu

Untuk memperoleh data suhu yang terjadi selama proses distilasi maka digunakan sensor suhu berupa sensor LM35. Sebelum digunakan dalam sistem kontrol maka sensor tersebut perlu diketahui karakteristiknya agar diperoleh pembacaan suhu yang akurat. Pada Gambar 3. memberikan informasi berupa grafik karakteristik sensor perbandingan antara sensor suhu dengan alat ukur termometer untuk menentukan keakuratan pengukuran suhu sensor.

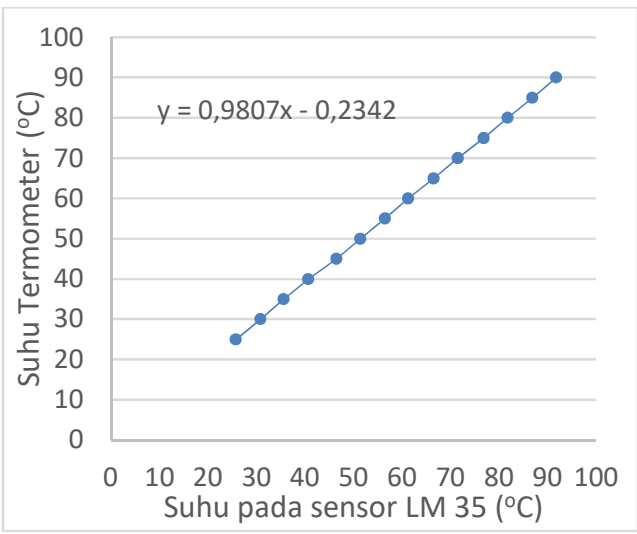

Gambar 3. Grafik perbandingan suhu sensor vs termometer

Dari grafik ini dapat diamati bahwa perbandingan antara suhu yang terbaca di sensor dengan suhu termometer terlihat linier, namun jika diamati secara detail ada sedikit selisih pembacaan suhu antara keduanya. Ini dibuktikan dengan persamaan garis yang dihasilkan, sehingga dapat dikatakan terdapat eror pembacaan pada sensor suhu.

Sedangkan dari data numerik penelitian, diketahui bahwa sensor memiliki rata-rata selisih suhu sebesar $1,37^{\circ} \mathrm{C}$ dengan selisih terbesar berada pada pembacaan suhu sebesar $85^{\circ} \mathrm{C}$. Informasi dari datasheet sensor (Texas Instruments, 2017) menunjukkan bahwa nilai maksimum pengukuran berada pada suhu $150^{\circ} \mathrm{C}$, sehingga dari data hasil percobaan yang dilakukan dapat dikatakan semakin tinggi suhu yang diukur maka semakin menurun akurasinya hingga 2,38\%. Meskipun terdapat selisih pengukuran namun penggunaan LM35 sebagai sensor masih dapat ditoleransi, karena batas pengukuran suhu hanya dibatasi sampai $100^{\circ} \mathrm{C}$ yang berkaitan dengan titik didih air dalam proses distilasi air laut.

\section{Pengujian Sensor Ke Dalam Sistem}

Karakter sensor yang mampu membaca perubahan suhu dari $-55^{\circ} \mathrm{C}$ sampai dengan $150^{\circ} \mathrm{C}$ sudah cukup memenuhi syarat agar dapat digunakan dalam sistem yang dibuat, karena rentang pengukuran suhu sistem dibatasi dari suhu $20-100^{\circ} \mathrm{C}$ sesuai dengan suhu normal air dan titik didih air.

Data hasil pengujian sensor disajikan pada Tabel 1. Suhu awal pengujian ditetapkan sebesar $30^{\circ} \mathrm{C}$ sebagai pendekatan dari suhu normal air, sehingga ketika suhu berada di bawah $30^{\circ} \mathrm{C}$ tegangan listrik sebesar 220 Volt mulai dihubungkan pada elemen pemanas dan memulai proses distilasi air laut. Sedangkan pada pembacaan suhu yang melebihi $100^{\circ}$ $\mathrm{C}$ sistem akan memutuskan sumber tegangan (0 Volt) untuk memastikan suhu proses distilasi tidak melebihi suhu air mendidih.

Proses ini ditujukan agar perangkat desalinasi yang dibangun memiliki pengelolaan sumber daya listrik yang efisien, karena jika tandon distilasi memiliki suhu di atas $100^{\circ} \mathrm{C}$ dan elemen pemanas tetap menyala maka akan terjadi pemborosan energi listrik. Sehingga dengan membuat sistem seperti ini dapat menghemat penggunaan sumber listrik dari sel surya yang tersimpan di aki.

Hasil pengujian diulang sebanyak tiga kali untuk memastikan sistem telah bekerja dengan baik. Dari seluruh pengujian pada suhu $30-100^{\circ} \mathrm{C}$ sistem menunjukkan bekerja dengan sempurna. Namun terjadi kendala kecil pada pembacaan suhu $101^{\circ} \mathrm{C}$ yang seharusnya elemen pemanas mati ternyata masih menyala. Akan tetapi hal ini sesuai dengan hasil pengujian karakteristik sensor sebelumnya yang diperoleh rata-rata selisih pembacaan suhu sebesar $1,37^{\circ} \mathrm{C}$, sehingga ketidakakuratan ini masih dalam batas wajar. 
Tabel 1. Tabel hasil uji pengukuran sensor LM35

\begin{tabular}{ccccc}
\hline No. & $\begin{array}{c}\text { Suhu } \\
\left({ }^{\circ} \mathrm{C}\right)\end{array}$ & Uji Ke-1 & $\begin{array}{c}\text { Tegangan (Volt) } \\
\text { Uji Ke-2 }\end{array}$ & Uji Ke-3 \\
\hline 1 & 30 & 220 & 220 & 220 \\
2 & 35 & 220 & 220 & 220 \\
3 & 45 & 220 & 220 & 220 \\
4 & 55 & 220 & 220 & 220 \\
5 & 65 & 220 & 220 & 220 \\
6 & 75 & 220 & 220 & 220 \\
7 & 85 & 220 & 220 & 220 \\
8 & 95 & 220 & 220 & 220 \\
9 & 100 & 220 & 220 & 220 \\
10 & 105 & 0 & 0 & 0 \\
\hline
\end{tabular}

Ketika suhu berada pada $105^{\circ} \mathrm{C}$ ketiga pengujian secara akurat menunjukkan bahwa sistem dengan akurat melaksanakan tugasnya untuk menghemat energi dengan cara memutus aliran listrik ke elemen pemanas. Oleh karena itu sesuai tabel pengujian dapat kita katakan bahwa perangkat memiliki tingkat akurasi sebesar $\pm 5^{\circ} \mathrm{C}$ dalam penghematan energi listrik.

\section{Hasil Produksi Perangkat}

Salah satu hasil produksi dari prototipe desalinasi dual output yang dibangun oleh peneliti berupa kristal garam. Karena secara fungsi perangkat ini bisa menghasilkan air tawar dan kristal garam secara bersamaan, namun kualitas dari air tawar yang diproduksi masih dalam tahap pengembangan. Oleh karena itu kali ini peneliti hanya membahas mengenai hasil produk berupa garam saja.

Perangkat dengan konsep serupa juga telah dikembangkan oleh Iswadi (Iswadi and Aisyah, 2013), di mana perangkat yang dikembangkan juga ditenagai oleh matahari, namun sinar matahari dalam perangkat tersebut digunakan secara langsung untuk memanaskan atau menguapkan air laut, sehingga memiliki kekurangan dari segi kapasitas produksinya yang tergantung dari cuaca dan harus selalu cerah serta tak berawan. Agar garam yang diproduksi bisa diperoleh secara maksimal maka waktu efektif hanya saat siang hari saja. Berbeda dengan alat yang dibangun oleh peneliti ini, di mana perangkat yang digunakan menggunakan tenaga listrik dari panel surya yang disimpan dalam baterai sehingga sepanjang hari mampu memproduksi garam bahkan di saat malam hari ketika tidak ada sinar matahari.

Garam yang dihasilkan oleh perangkat tertampung di tandon penampungan air laut, jadi karena proses distilasi komponen air pada air laut akan menguap dan menyisakan residu berupa kristal garam yang tertinggal di dalam tandon penampungan. Dapat dilihat pada Gambar 4 adalah bentuk dari tandon penampungan yang di dalamnya terdapat berkas berwarna putih yang merupakan kristal garam. Tandon penampungan mampu menampung air laut sebesar 6,3 liter sehingga kapasitas produksi dari perangkat dapat diperkirakan sebesar \pm 220 gram garam dalam sekali pengoperasian.

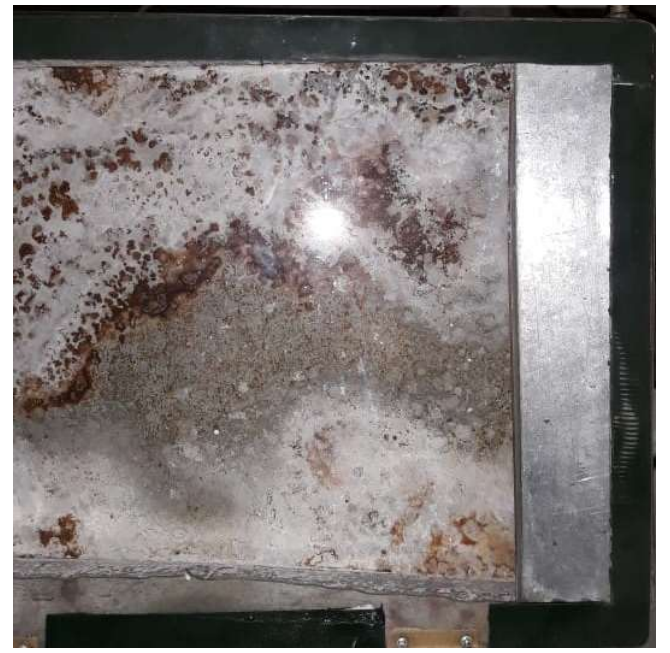

Gambar 4. Tandon penampung garam

Bentuk garam hasil produksi masih berupa gumpalan seperti Gambar 5 sehingga masih perlu pengolahan lebih 
lanjut agar bisa digunakan untuk kebutuhan rumah tangga.

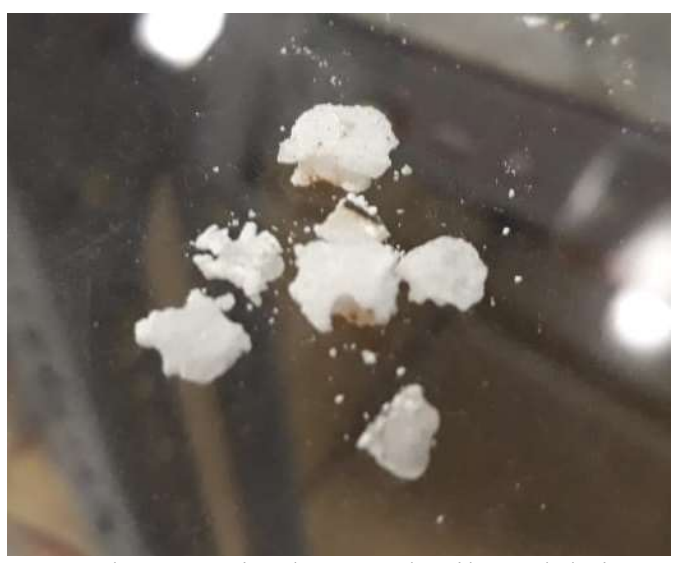

Gambar 5. Kristal garam hasil produksi

\section{KESIMPULAN}

Penggunaan sensor suhu pada perangkat prototipe desalinasi dual output bertenaga energi terbarukan dapat digunakan sebagai komponen sistem otomatisasi pemanas distilasi untuk menghemat kebutuhan energi listrik yang terbatas pada sistem sel surya. Efisiensi energi ini dapat terjadi dengan mengondisikan suhu pemanas tidak lebih dari $100^{\circ} \mathrm{C}$ sehingga tidak ada pemborosan daya listrik pada suhu ketika suhu melebihi titik didih air.

\section{UCAPAN TERIMA KASIH}

Peneliti mengucapkan terima kasih kepada seluruh dosen Program Studidi Teknik Elektro yang telah memberikan masukan, juga kepada Dekan Fakultas Teknik Industri serta Kepala Laboratorium Teknik Elektro Universitas PGRI Adi Buana Surabaya yang telah menyediakan fasilitas dalam proses penelitian ini.

\section{DAFTAR PUSTAKA}

Iswadi, and Aisyah (2013): Sistem Pengolahan Air Laut Menjadi Air Minum Menggunakan Tenaga Matahari, Al-Kimia, 1, 66-77.

Lubis, A. (2007): Energi Terbarukan Dalam Pembangunan Berkelanjutan, 8, 155-162.

Lubis, R. F. (2018): Indonesia Negeri Tropis, Tapi Krisis Air Bersih di Kawasan Pesisir Terjadi?, retrieved December 4, 2018, from internet: http://lipi.go.id/berita/single/Indonesia-Negeri-Tropis-Tapi-Krisis-Air-Bersih-diKawasan-Pesisir-Terjadi/20218.

Sahoo, M. K., and Kale, P. (2018): Integration of silicon nanowires in solar cell structure for efficiency enhancement: A review, Journal of Materiomics. https://doi.org/10.1016/j.jmat.2018.11.007

Service, R. F. (2005): Is It Time to Shoot for the Sun?, 309(5734), 548-551. https://doi.org/10.1126/science.309.5734.548

Sumada, K., Dewati, R., and Suprihatin (2018): Improvement of seawater salt quality by hydroextraction and re-crystallization methods, Journal of Physics: Conference Series, 953, 012214. https://doi.org/10.1088/1742-6596/953/1/012214

Suryana, D., and Ali, M. M. (2016): The Effect Of Temperature On Voltage Produced By Monocrystalline Solar Panel, 2, 49-52.

Texas Instruments (2017): LM35 Precision Centigrade Temperature Sensors, Texas Instruments Incorporated, Dallas.

Zheng, H. (2017): Chapter 1 - General Problems in Seawater Desalination, 1-46 in H. Zheng, ed., Solar Energy Desalination Technology, Elsevier, Amsterdam. https://doi.org/10.1016/B978-0-12-805411-6.00001-4 